\title{
ENERGY SECURITY - IN A CLINCH BETWEEN POLITICS AND BUSINESS. CHOSEN ALTERNATIVE ENERGY SOLUTIONS ${ }^{1}$
}

Energy security is one of the targets of energy policy adopted by modern states and more and more by supranational structures. At the same time, it is a precondition for a country's economic growth and the society's well-being. ${ }^{2}$ In the $21^{\text {st }}$ century, we depend on both primary (like electricity) and secondary energy carriers. Among the latter, oil and natural gas have played and still play an important role in the foreign policies of a number of states. ${ }^{3}$

As the well-known and influential political scientist Sergey Karaganov ${ }^{4}$ once said, "using oil and natural gas as a foreign policy instruments is absolutely unacceptable", adding at the same time that, "it is absolutely impossible not to do so either". Therefore, it is necessary to take into account that in international relations we will have to deal with such instruments of policy-making. They may be acceptable as long as their use does not harm the interests of partners or they do not become a sort of energy weapon, ${ }^{5}$ as was the case for the so-called gas wars waged by Gazprom. ${ }^{6}$

Therefore, there is some question as to whether we have in mind energy production, our future, the future of our planet, or only political expansion. This question is justified in so far as a substantial part of energy sources, whose depletion and disastrous effects on climate are touched upon by the same people, could already be successfully replaced, but for resistance from political elites and business. The author does not claim the be a technical expert in energy. The article is supposed to represent a contribution to the discussion on the future of world energy production. The concepts referred to might seem pointless, unreal, trivial, or plain ridiculous, but, as Albert Einstein replied to the question of where inventions came from, "Everybody knows that some-

1 Work on the main body of the article was finished on December 6, 2011.

2 Panel dyskusyjny na XX FE: Bezpieczeństwo Energetyczne Polski - prezentacja Raportu Instytutu Kościuszki, http://ik.org.pl/pl/wydarzenie/nr/3535/ (8.07.2011).

3 A. Kupich, review: Geopolityka rurociagów. Wspótzależność energetyczna a stosunki międzynarodowe na obszarze postsowieckim, (ed.) E. Wyciszkiewicz, Warszawa 2008, http://www.pism.pl/ files/?id_plik=3385 (8.07.2011).

4 Ibidem. See also: KARAGANOV, Sergey Alexandrovich, http://russiaprofile.org/bg_people/resources_whoiswho_alphabet_k_karaganov.html (8.07.2011); and http://karaganov.ru/en (8.07.2011).

5 A. Kupich, review: Geopolityka, op. cit.

${ }^{6}$ See also: Ł. Donaj, A. Kucenko, Gazprom i jego wpływ na wspótczesne bezpieczeństwo energetyczne Unii Europejskiej. Wybrane problemy, "Przegląd Strategiczny" 2011, No. 2. 
thing cannot be done, and then somebody turns up, and he doesn't know it can't be done, and he does it". ${ }^{7}$

A number of people are working on the more efficient use of renewable energy sources and restrictions on energy wasting. The majority of efforts will probably result in small and beneficial improvements. They are needed, but so are radical solutions. Scientists and engineers have had visions of wind power stations hanging in the air or satellites sending concentrated solar radiation beams to receivers on Earth for years. They seemed a fantasy world, but it turns out that scholars have recently been given substantial funds, government and private, for similarly daring projects. ${ }^{8}$ Below are cited both radical and what will be referred to as supportive solutions.

Fusion-Driven Fission. The suppression of nuclear fusion, the process that powers the Sun and is used in hydrogen bombs, has been researched for years. Scientists have no problems with its generation - the fusion of hydrogen nuclei so that there is a synthesis of neutron emission and a release of energy. The problem is to generate more energy in the reaction than is needed for its launch. Scientists from the National Ignition Facility in Livermore, California, approached the issue differently: they want to use fusion to cause fission of atomic nuclei, a process used in conventional reactors. The director of the Facility Edward Moses says that such a prototype power station should be established in about 20 years. ${ }^{9}$

Solar Petrol. Within an hour, the Sun provides the Earth with more energy than our civilization uses for a year. If we managed to convert even a fraction of that surplus into a liquid fuel, it would mean the end not only to the dependence of transport on fossil fuels, but also the problems caused by them. "Chemical fuel directly generated from sunlight would completely alter our situation if only it could be efficiently and inexpensively generated", says Nathan Lewis, the director of the Joint Center for Artificial Photosynthesis of the California Institute of Technology. ${ }^{10}$

In one of the most interesting projects materialised in the Sandia National Laboratories, a 6-meter wide dish of mirrors, located in the desert in New Mexico, is used. It focuses the Sun's rays on a half-meter long machine, cylindrical and looking like a barrel of beer, placed in front of the dish. Concentrated sunlight falls through a window in the walls of the machine on a dozen concentric rings rotating at a speed of one revolution per minute. Their serrated edges are made of iron oxide or cerium oxide. With the rotation of a ring, oxides hit the light beam area, where they are heated to $1500^{\circ} \mathrm{C}$. At this temperature, the oxides decompose and release oxygen. Then, as the rotation progresses, the rings reach the dark, cooler part of the reactor. There, they pick up oxygen

7 S. Bratkowski, O właściwe podejście do rzeczy niemożliwych, http://polidea.pl/Articles/10045,0,O\%20właściwe\%20podejście\%20do\%20rzeczy\%20niemożliwych (12.11.2006).

8 Radykalne rozwiqzania w energetyce - redakcja Scientific American, "Świat Nauki" 2001, No. 6 .

${ }^{9}$ G. P. Collins, Elektrownie. Rozszczepienie inicjowane fuzja. Pozyskiwanie energii elektrycznej ze zużytego paliwa jadrowego, in: Radykalne rozwiazania w energetyce, op. cit. See also: Inertial Fusion Energy, https://lasers.llnl.gov/programs/ife/ (8.07.2011).

10 D. Biello, Paliwa ciekłe. Stoneczna benzyna. Skupiona energia stoneczna i dwutlenek węla napędzaja pojazdy, in: Radykalne rozwiazania w energetyce, op. cit. See also: The Joint Center for Artificial Photosynthesis, http://solarfuelshub.org/ (8.07.2011). 
from gases - water vapour or carbon dioxide - pumped into the chamber, thus producing high-energy gases: hydrogen or carbon monoxide. The mixture of $\mathrm{H}_{2}$ and $\mathrm{CO}$ generated by this process, known as synthesis gas (syngas), contains the basic elements that make up the organic compounds that make up fossil fuels, various chemicals, and plastics. Additionally, the process consumes as much $\mathrm{CO}_{2}$ as is released during the combustion of the fuel produced. "Such a system for generating solar fuel is four in one", indicates Arun Majumdar, the director of the Advanced Research Projects Agency-Energy: a source of clean fuels, greater energy security, reduction of $\mathrm{CO}_{2}$ levels, and limiting climate change. ${ }^{11}$

This does not mean that all the problems have been overcome. The wheel surrounds in Sandia still burst, inhibiting the process. "The temperature jumping from $1500^{\circ} \mathrm{C}$ to $900^{\circ} \mathrm{C}$ and back strains the material", notes Gary Dinks, a chemist and the director of LightWorks of Arizona University, not involved in the project. The next step will be to improve the structure of the oxide border at the nanoscale or to find a better material. The high costs of the mirrors also need to be reduced. Researchers at Sandia say that their device will be able to produce fuel at 10 dollars per gallon (depending on the level of world prices, about 2.65 dollars per litre). "Everything shows that it is possible", says the chemical engineer and inventor of the device Jamek E. Miller, "but the road is still far from over". ${ }^{12}$

Solar energy can of course be used in a more "traditional" way, through solar power plants. Each day sees information about new, more efficient power plants. ${ }^{13}$ In April 2011, it was announced that the largest solar power plant the Ivanpah Power Tower would be established in the Mojave Desert in California. Google (which decided to invest 168 million dollars in its construction) compared its operation to remove 90,000 cars from the road that would not produce greenhouse gases for at least 25 years. When the construction of the Ivanpah Solar Electric Generating System (ISEGS) in the Mojave Desert has been completed, which is planned for 2013, it will produce $392 \mathrm{MW}$ of clean electricity. Built in a desert, the plant is called a solar tower. 347,000 mirrors, called heliostats, will focus the Sun's rays on three tanks of water placed in 137-meter high towers situated in the centre of the power plant. High temperatures will convert water into steam, which in turn will drive a turbine producing electricity. ${ }^{14}$

11 D. Biello, Paliwa ciekte. Stoneczna, op. cit., http://www.sandia.gov/ (8.07.2011). See also: D. Appell, Klimat. Kłopotliwe dane. Prozaiczne błędy podkopaty społeczne zaufanie do orędowników walki z ociepleniem klimatu, "Świat Nauki" 2009, No. 9; Sceptycy zmian klimatu, http://ziemianarozdrozu.pl/artykuly/sceptycy-zmian-klimatu? $\mathrm{p}=2$ (8.07.2011); and The Discovery of Global Warming, http://www.aip.org/history/climate/index.htm (8.07.2011).

12 D. Biello, Paliwa ciekte. Stoneczna, op. cit.

13 See: Elektrownia słoneczna na pustyni Gobi. Chińczycy inwestuja na pustyni Gobi, "21.Wiek" 2007, No. 6; Portugalia: największa na świecie elektrownia słoneczna, PAP, http://www.wnp.pl/wiadomosci/portugalia-najwieksza-na-swiecie-elektrownia-sloneczna,22263_1_0_0.html (8.07.2011); and Elektrownia stoneczna w Australii za $1 \mathrm{mld}$ \$, http://www.elektroonline.pl/news/1464,Elektrownia_sloneczna_w_Australii_za_1_mld_(8.07.2011).

${ }_{14}$ Ivanpah Solar Electric Generating System - największa elektrownia słoneczna świata, http://forsal.pl/artykuly/505324,ivanpah_solar_electric_generating_system_najwieksza_elektrownia_sloneczna_swiata_zdjecia.html (8.07.2011). 
Lunar Energy. Some place solar panels on roofs, others place them in vast deserts, and still others plan to put them on the Moon. Engineers from the Japanese company Shimizu (figure 1) proposed a plan for a ring of solar panels around the silver orb. The energy collected in this way would be sent to receiving stations in all corners of the world. The idea is not new, it was born at a time when amazing ideas were hatched up with particular ease. In 1968, the American engineer Peter Glaser proposed two ways to send solar energy from space to Earth. One required an army of large geostationary satellites (i.e., ones that are always in the same position relative to the Earth). They were to be equipped with huge solar panels. This idea was unrealistic - building and sending such a mass of cells into orbit would be too expensive. Therefore, experts immediately drew their attention to the other version of the plan, i.e., putting solar power plants on the Moon. Although the Moon is much further than stationary orbit, it would cost less, because there would be no need for sending solar panels from Earth. It would be enough to dispatch some machines, a handful of people and to produce batteries on the spot. The necessary elements are in abundance in the lunar soil. There is no need to specifically look for and mine them. Dust from any place on the silver orb will contain $20 \%$ of silicon, $40 \%$ of oxygen, and $10 \%$ of metals (iron, aluminium, titanium, etc.). On the Moon, there is all that is needed to produce not only photovoltaic cells, but also the cables and antennas for sending energy to Earth. Because raw materials are distributed evenly, they will not even need to be carried from one part of the Moon to another, but will always be on site. The question is how to send the energy to the Earth. Scientists have known the answer to this question for decades - microwaves. According to the original plan by Peter Glaser, energy from the Moon would be sent in the form of multiple beams of microwaves (12 cm wavelength). First, they would be sent to relay stations on artificial satellites and only from there to receiving antennas (called rectennas) on Earth. The relay stations could send energy to any point on the planet as long as a rectenna was there. Unlike light, microwaves filter through the atmosphere perfectly, regardless of rain, clouds, snow, fog, or smoke. As Peter Glaser calculated, it is enough to send a beam of a magnitude not greater than one-fifth of the intensity of sunlight at noon to get $200 \mathrm{~W}$ per square metre of rectenna. To get the said $20 \mathrm{TW}$ of power, you would have to cover 100,000 square kilometres with rectennas, which is an area corresponding to $30 \%$ of the territory of Poland. And that would provide all mankind with energy. If we wanted to generate similar power from modern solar panels on Earth, they would have to cover a surface twenty times greater. The project presented by Shimizu differs slightly from P. Glaser's. The American engineer planned to put solar panels in several dozen points on the eastern and western edges of the Moon (as seen from Earth). The Japanese would surround the entire silver orb with a ring of panels. They also propose that microwaves as well as laser be used for the transmission of energy and that the receiving stations be at sea so as to immediately use the power of the Moon to produce hydrogen from water. Regardless of the details of the idea, it is still alive and every now and then returns in a new incarnation. Will it ever be realized? As pointed out by L. Kaniewski, it does not really depend on scientists and engineers: the theoretical and technical issues have been more or less resolved. The matter of finance remains an issue: the transport of people and machines to the Moon costs far too much. There is also a more subtle nature of the problem, in that people (and especially NASA) have lost in- 
terest in the Moon. They plan missions to Mars, they want to look for microorganisms on Europa (a moon of Jupiter), whereas the nearby Moon, conquered long ago, has ceased to excite them. Unfortunately, it seems that we are looking for life in space and have forgotten about life on Earth. ${ }^{15}$

Figure 1. Sending Solar Energy to the Earth

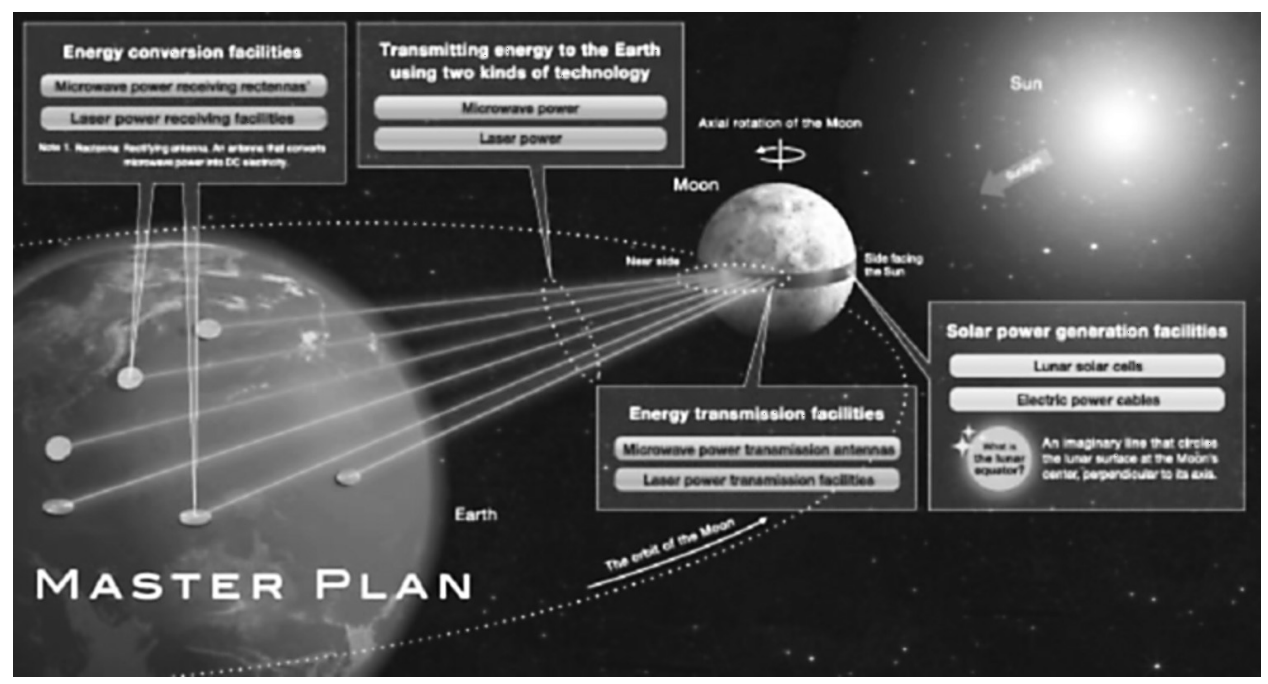

Source: Lunar Solar Power Generation - LUNA RING, http://www.shimz.co.jp/english/theme/dream/ lunaring.html (8.07.2011).

Since lunar energy (actually, solar energy sent from the silver orb) has been mentioned, the ideas of using helium-3 are worth mentioning too. Helium-3 is a special type of gas used to fill balloons, but also used as a coolant in nuclear reactors or in medical devices that use magnetic resonance imaging. The reaction of helium-3 with deuterium releases a tremendous amount of heat that can become a great source of energy. At the same time, there is no hazardous waste as in a nuclear reactor. "Just 25 tonnes of helium-3 would be enough to provide electricity in the U.S. for a year", assessed Lawrence Taylor of the U.S. Planetary Geosciences Institute, Department of Earth and Planetary Sciences. The Earth has only $10 \mathrm{~kg}$ of this wonderful gas, though. The study of samples brought by the Americans suggests that large quantities, brought by the solar winds, are on the Moon. The Indian scientist APJ Abdul Kalam believes that on the Moon there is 10 times more energy in the form of helium-3 than on Earth in the form of all fossil fuels. Today, energy concerns from China and Russia are racing to gain access to oil and gas, but in a few years the world will run out of its hydrocarbon resources. If there are none on Earth, we must search around in space. Therefore, the superpowers are preparing for the race for new energy sources. "By 2015, Russia will have been able

15 Ł. Kaniewski, Energia księżycowa, http://www.focus.pl/technika/zobacz/publikacje/energia-ksiezycowa/nc/1/ (8.07.2011). See also: Ubiquity. Information everywhere, http://ubiquity.acm.org/ (8.07.2011); http://www.shimz.co.jp/english/theme/dream/lunaring.html (8.07.2011). 
to send a manned mission to the Moon," Nikolai Sevastyanov, the CEO of RKK Energy, a major Russian aerospace manufacturer, said a few years ago. But it is not just that the Russians have the ambition to match the Americans, who first stood on the Moon. A Russian manned mission to the Moon provided a foothold for an ambitious program to exploit lunar helium-3 deposits. N. Sevastyanov believed that this program could start in 20 years. The Russians are in a hurry, because plans for expeditions to the Moon have been disclosed by the Chinese. In 2017, the Middle Kingdom intends to send a space probe for a sample of soil from the Moon. Even before that the Chinese said they wanted to see if the import of helium-3 from there would pay off. In 2004, in India at a conference on the use of the Moon, scientists estimated that 200 tonnes of lunar soil after heating would give one tonne of helium-3. You just need to organize a fleet of space shuttles to bring gas to the Earth. The Russians then calculated that the exploitation and transport of lunar helium-3 resources would cost an astronomical amount of 40 to 200 billion dollars. But the investment would quickly pay for itself through the sale of gas produced from the energy. The trouble is that at the moment work on the construction of reactors treating helium-3 is still in its infancy, and perhaps it will be easier to bring the gas from the Moon than to use it. ${ }^{16}$

Quantum Photovoltaics. Commercially available solar cells are only $10-15 \%$ efficient, which makes their practical use unprofitable. One reason is the theoretical limit of the efficiency of a single layer of light-absorbing silicon of approximately $31 \%$ (the most efficient solar panels, used for scientific research purposes, reach $26 \%$ ). New research in the field of quantum dots could move this limit to above $60 \%$, enabling the production of solar cells producing electricity at competitive costs. ${ }^{17}$

Heat Engines. Data indicate that as much as $60 \%$ of the electricity produced in the U.S. is wasted, the majority lost in millions of power plants. Researchers at General Motors in Warren, Michigan, are trying to capture this energy, using alloys with shape memory. They can convert heat into mechanical energy, which in turn can be easily converted into electricity. The team leader, Alan Browne, plans to use strips of thin, parallel bands of nickel and titanium alloy that has the ability to "remember" a specific shape. This property makes it able to pass from one state to another and back again, in this case from an initial stiff state at a high temperature to a more flexible state at a low temperature. The prototype should be seen more as a demonstration of the working principle rather than a device with a practical application - the power generated is small, but $\mathrm{A}$. Browne says that within a decade a device operating on a larger scale will

16 A. Kublik, Rosja i Chiny walczq o energię z Księżyca, http://m.wyborcza.biz/biznes/1,106501, 3278653.html (8.07.2011); Górnictwo na Księżycu, http:/www.focus.pl/nauka/zobacz/publikacje/gornictwo-na-ksiezycu/ (8.07.2011); Wyścig na Księżyc po mineraty już się rozpoczat, http://deusexgame.wordpress.com/2009/03/07/wyscig-na-ksiezyc-po-mineraly-juz-sie-rozpoczal/ (8.07.2011); and Niemcy planuja bezzałogowy kosmiczny lot księżycowy (aktl.), PAP, http://wiadomosci.gazeta.pl/Wiadomosci/1,80708,3957017.html (8.07.2011).

17 J.R. Minkel, Elektryczność. Kwantowa fotowoltanika, in: Radykalne rozwiqzania w energetyce..., op. cit. See also: Kropki kwantowe zamiast żarówek, http://www.lukas-home-page.ovh.org/ wiadomosci/Kropki_kwantowe_zamiast_zarowek.php (8.07.2011); and J. Peszke, Mały może więcej - kropka kwantowa, http://www.nanonet.pl/index.php?option=com_content\&task=view\&id=105\&Itemid=65 (8.07.2011). 
be developed, ready to be launched onto the market, and adds that no technical issues preclude the use of thermal engines using a shape memory alloy in household appliances or power plant cooling vents. ${ }^{18}$

The engineering team at Michigan State University under the leadership of Norbert Muller has recently unveiled an innovative engine that uses shock waves to compress an air-fuel mixture. The principles of the project were simple: to increase the efficiency of the drive unit in relation to traditional internal combustion engines, to reduce emission of harmful gases, and to minimize production costs. The project can be said to have been successful, because the prototype developed by the American scientists provisionally adheres to these principles. The design is called a wave disk engine. Its main element is a rotor with vanes that, in combination with the side walls of the engine, form smaller compartments inside the main compartment. During the rotation of the rotor, the air-fuel mixture is transported to the chamber through special channels. The mixture is locked in, because during the rotation the outlet channels are blocked. This causes a pressure increase, which in turn causes a shock wave. The mixture is then compressed. After the wave has passed, the central channels are blocked. The mixture ignition occurs, causing a rotation that opens the outlet channels. Then in a very violent way the gases are ejected, which sets the rotor blades in motion (figure 2). In this way, electricity can be easily and efficiently produced. The unit is revolutionary, because it allows much greater efficiency than a normal combustion engine. N. Muller's design achieves an efficiency of up to $60 \%$, while the remaining units range from 25 to $40 \%$.

Figure 2. Shockwave Engine

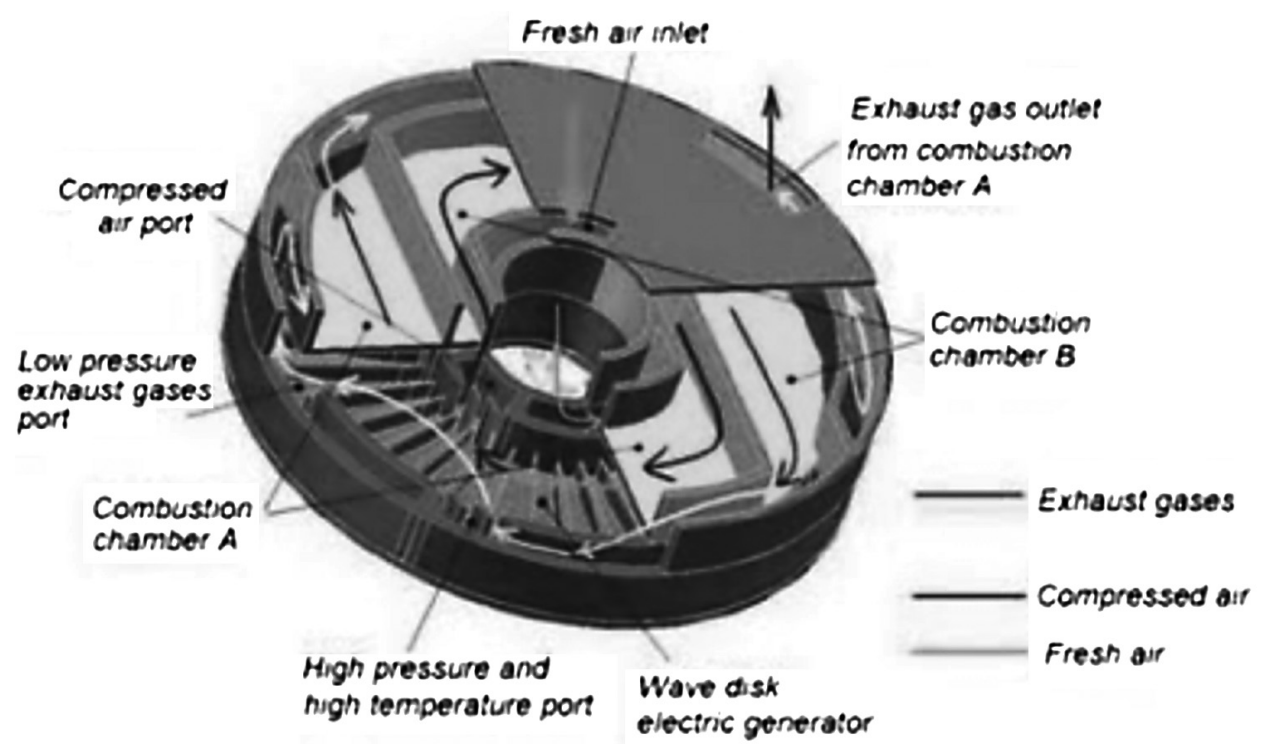

Source: Wave Disc Engines, http://nextbigfuture.com/2009/10/wave-disc-engines.html (8.07.2011).

18 See: B.P. Trivedi, Odzyskiwanie energii. Silniki cieplne, in: Radykalne rozwiazania $w$ energetyce, op. cit. 
According to preliminary calculations, the wave disk engine allows the reduction of one third of production costs. It also simplifies the construction of the propulsion system, as it does not need such elements as pistons, camshafts, or valves. Simpler mechanisms reduce losses, and consequently, the need for fuel. This type of engine is also likely to appear soon in cars on our roads. The constructor developed it with the idea of assisting hybrid systems. According to preliminary estimates, the new engine would have a range of a few hundred kilometres greater compared to conventional powers units. ${ }^{19}$

And since we have mentioned cars and how they can be refuelled/powered, the concept of a compressed air car is worth mentioning too. In Geneva in 2009, just such a car was presented. The idea of building such a model is simple. A cylinder mounted in a car with a capacity of 175 litres is filled with air, compressed at a pressure of 350 atmospheres. To put it simply, the principle of the "air motor" is that compressed air is directed at a special turbine, forcing it to move. On the axis, where the turbine is, there is also a generator rotor. The unit generates electricity which powers the electric motor that drives the wheels. The idea is very easy, but its use is possible only if the vehicle weighs very little. This model (including the cylinder with compressed air) is made of plastic and carbon fibre. As a result, its total weight is only $220 \mathrm{~kg}$. The cost of using this vehicle is also worth mentioning. According to the calculations by car manufacturers, the only cost, the use of electricity in the air compressor, comes to merely 0.5 Euro per $100 \mathrm{~km}$ ! Is the problem solved, then? Unfortunately, not quite. Since a car must have a minimum weight, it is impossible-for now-to build a sports, family, or off-road vehicle model. The model presented in Geneva is a typical rickshaw, with a driver's seat and two seats for passengers, facing rearward. Although the interior of Air is fully electronic and has a navigation system, this does not change the fact that it is just a luxury rickshaw. ${ }^{20}$ It should be noted that the actual idea of "air power" is not new and that one of its originators was the Polish engineer Louis Mękarski, who more than 130 years ago developed an experimental air motor to drive trams. In 1872 and 1873, he patented his design and in 1876 tested it on the TN line in Paris. L. Mękarski's trams were very popular in France in the late $19^{\text {th }}$ and early $20^{\text {th }}$ centuries. They were used in cities such as Nantes, Paris, Vichy, Aix-les-Bains, Saint-Quentin, and La Rochelle. ${ }^{21}$

Magnetic Conditioners. Air conditioners, refrigerators, and freezers require huge amounts of energy. In the United States, they account for one third of all the energy used by households. Enormous savings can be brought by innovative technologies based on the use of magnets. Most commercially available refrigeration equipment operates on the principle of the cyclical compression and expansion of a refrigerant. Compressors,

19 See: S. Kościółek, Silnik z falq uderzeniowa, http://www.motogazeta.mojeauto.pl/Technika/Silnik_z_fala_uderzeniowa,a,186203.html (8.07.2011); S. Ashley, Pojazdy. Silnik z falq uderzeniowa, in: Radykalne rozwiqzania w energetyce, "Świat Nauki" 2011, No. 6; Wave Disc Engines, http://nextbigfuture.com/2009/10/wave-disc-engines.html (8.07.2011).

${ }_{20}$ Samochód na powietrze, (BK), http://moto.wp.pl/kat,107714,title,Samochod-na-powietrze, wid,10917384, wiadomosc.html?ticaid=1ca06 (8.07.2011); Wystarczy mu powietrze, "Focus" 2009, No. 6 .

${ }^{21}$ Tata Air Car - samochód na powietrze, http://autokult.pl/2008/07/01/tata-air-car-samochod-na-powietrze (8.07.2011). 
however, are real energy guzzlers, not to mention the gases inside that are harmful to the atmosphere. Researchers at the Astronautics Corporation of America in Milwaukee are developing a cooling system that, by using a magnet, requires no compressor. Some magnetic materials, substances responding to magnetic fields, show a very interesting property. When placed in a strong magnetic field and then turned off, they cool off. This phenomenon is known as adiabatic demagnetisation and the magnetocaloric effect in English. It was discovered in 1881, but has not so far found a practical application, because in all previously known magnetics it was observed only at the temperature of liquid helium. But in 1997, Ames Laboratory material experts from the U.S. Department of Energy in Iowa, working with Astronautics, discovered a gadolinium, silicon, and germanium alloy, creating the so-called gigantic magnetocaloric effect at room temperature. Since then, scientists have invented other alloys with similar properties. At the moment, plans to use such alloys are expensive, but they show great potential, and a level of productivity can be achieved. ${ }^{22}$

Although in 2030 our energy balance will change and renewable energy will become of significant importance, and after the 2020 the first nuclear power plants will be established in Poland (although after the Japanese nuclear power plant accident in the Fukushima Daiichi Nuclear Power Plant and Germany's decision to abandon nuclear power, the matter is not a foregone conclusion), the "Polish Energy Policy Until 2030" provided that coal power plants would remain the country's energy security stabilizers. ${ }^{23}$

Coal and most of the organic sources of energy are considered responsible for climate change although it needs to be admitted that opinions about this differ. It is therefore even more reasonable to search for other ways to use coal. Engineers have developed many methods of removing carbon dioxide from the combustion gases of coal-fired power plants before they enters the atmosphere, but the cost of this process reaches $30 \%$ of the energy driven from the coal, which would result in a twofold increase in its price. However, the idea itself is so attractive that the Department of Energy's Advanced Research Projects Agency-Energy and other agencies are funding research that will reduce the proportion of these losses. ${ }^{24}$

Beneath the surface of the earth is an enormous amount of thermal energy. From time to time, it escapes to the surface as lava, hot water, or gases. Its sources lie usually very deep, but low-temperature geothermal resources (cooler than $150^{\circ} \mathrm{C}$ ), occur in many areas and can be used to heat homes, for recreation and health benefits, as well as in some industrial processes. ${ }^{25}$ Geothermal heating was first noticed and appreciated in the form of hot springs that ancient civilizations willingly used. The possibility of using

22 Ch. Q. Choi, Urzadzenia. Klimatyzatory magnetyczne, in: Radykalne rozwiazania, op. cit. See also: K. Gibson, Magnetic refrigerator successfully tested. Ames Laboratory develoments help push boundaries of new refrigeration technology, http://www.eurekalert.org/features/doe/2001-11/ dl-mrs062802.php (8.07.2011).

23 See: A. Lakoma, Polska energetyka zostanie przy węglu, http://www.rp.pl/artykul/293517.html (9.07.2011); M. Potocki, Niemcy zrezygnuja z atomu. Maja węgiel, http://gospodarka.dziennik.pl/news/artykuly/335565,niemcy-rezygnuja-z-atomu-wola-wegiel.html (9.97.2011); and A. Piore, Energetyka jądrowa. Czy zdołamy wszystko przewidzieć?, "Świat Nauki” 2011, No. 7.

24 See also: M. Lemonick, Emisja. Czyst(sz)y węgiel, in: Radykalne rozwiazania, op. cit.

25 Z. Gawryś, Czy pod ziemiq czeka nan nas energetyczne bogactwo?, “21. Wiek” 2006, No. 11. 
geothermal energy for electricity production was first accepted almost a hundred years ago by Prince Piero Ginori Conti. Since that time, with the development of technology and increased awareness, two methods of energy production have enabled people to produce both heat and electricity. One method, called Engineered Geothermal Systems (EGS), is used for energy production by means of two parallel boreholes in the Earth. One borehole pumps water into the earth to heat it up to about $200^{\circ} \mathrm{C}$, and the other is used to pump out the hot water and steam to the surface. The steam is used to drive a turbine, and the hot water heats houses and industrial plants. In the other system, called the Organic Rankine Cycle (ORC), wells are built deep into heat resources, and steam is separated from hot water under high pressure. The steam and hot water after separation are used to drive turbines in power plants. When the geothermal water is cooled, it returns to the tank where heats up again and is once more ready for use. ${ }^{26}$

The American biologist Bruce Rittmann, in turn, believes in the future of microbial fuel cells. His plans were to have bbbeen placed in orbit around the Earth. America's space agency NASA placed an order with him for a device that could produce electricity on board the space shuttle and the International Space Station from manure and various organic waste. B. Rittmann planned to use bacteria for this purpose. Unfortunately, NASA's budget cuts resulted in the stellar source of research funding drying up. The scientist is now forced to conduct research in more down-to-earth conditions. He is convinced that electricity can be produced from, for example, sewage directly in sewage treatment plants. Again, he wants to use bacteria that are able to generate huge amounts of organic compounds from free electrons. The first microbiological bacterial cell that can be used in practice was constructed in the USA at Oregon State University. It was used to power devices operating in remote locations, in lakes and rivers. An anode is immersed in mud on the river bed. The bacteria that cover it send it their electrons, which are then routed to the cathode, placed in well-oxygenated water near the surface. The device generates about $1 \mathrm{~W}$. This is quite sufficient to power manometers, thermometers, and other measuring instruments. The great advantage of microbiological bacterial cells is that they do not require any repairs or maintenance for long periods. ${ }^{27}$

The production of electricity by man is nothing new, see bicycle dynamos or crank radios, to name but a few. At present, there are muscular generators that produce electricity, for example, from walking. In most versions, pressure on the shoe sole is used, but the efficiency of such a generator is not high. Much more effective are backpacks with springs, but it is tiring to wear them. Researchers from Simon Fraser University in Canada decided to use the same principle as used in some hybrid cars and recover leg energy from braking. The generator, attached to the knee joints, has been tested on six subjects. Walking on a treadmill generated up to $5 \mathrm{~W}$ of power (when running, one of the men managed to generate $54 \mathrm{~W}$ ), which was enough to power 10 cell phones, and the extra effort was minimal. ${ }^{28}$

${ }^{26}$ Energia geotermalna coraz popularniejsza, http://www.egospodarka.pl/32963,Energia-geotermalna-coraz-popularniejsza, 1,56,1.html (9.07.2011).

27 Z. Gawryś, Ogniwa bateryjne z bakterii?, "21.Wiek" 2008, No. 1.

${ }^{28}$ Ludzki generator, (EW), "Wiedza i Życie" 2008, No. 3. See also: Crank Up Battery, http://www.yankodesign.com/2009/10/05/crank-up-battery/ (9.07.2011). 
Another version of using man as an energy source has been presented by scientists from Singapore. The device known as the thermoelectric generator, attached to the human body is capable of producing a couple of microwatts of energy, which is sufficient to power implants or wireless sensors. The authors of the invention are: Jin Feng Xie and Hanhua of the Institute of Microelectronics, A*STAR, the Singapore government's Agency for Science, Technology and Research, and Chengkuo Lee of the National University of Singapore. The entire generator consists of a chip the size of one square centimetre, equipped with over 20,000 thermocouples. The thermocouples, arranged in groups called thermoelectric piles, detect the temperature difference between a hot and cold link, creating tension. A temperature difference of $5^{\circ} \mathrm{C}$ allows the generation of 16.7 volts and 1.3 microwatts of power. The scientists hope that in future this result will be further improved so as to achieve a few microwatts. By accumulating the energy generated over time, the device could be used to extend the battery life powered electronic devices, such as pressure sensors. Powering medical implants in this way would eliminate the need to replace batteries, a difficult and costly operation. Although this is not the first device that generates energy from the warmth of the human body, it surpasses its predecessors in terms of efficiency. The researchers used, for example, a vacuum and a radiator to further increase the temperature difference between the side of the generator attached to the body and that exposed to the environment. As stated by J. Xie, "One of the assets of the device is that at the top and bottom there are vacuum areas that affect the increase of the temperature difference between thermocouple elements. Another is the radiator located on the cold side of the device which dissipates heat even further. Yet another are the holes on the edges, designed to isolate heat from the silicon substrate". Another advantage of the thermoelectric generator is that it is compatible with CMOS, which means that it can be produced on normal CMOS production lines. Thanks to this, the device can serve as a new source of energy for self-powered CMOS and MEMS devices which are characterized by low energy demand. ${ }^{29}$

As noted by Michio Kaku, ${ }^{30}$ predicting the future is a task beyond a single man. The scope of human knowledge is simply too broad. In fact, most forecasts are incorrect, because they reflect only the individual point of view of their creators. ${ }^{31}$ Hopefully, thanks

29 Generator energii z ciepła ludzkiego ciała, (lk), http://www.automatyka.pl/newsItem.aspx?pk=8086 (9.07.2011). See also: CMOS gates demonstration, http://tams-www.informatik.uni-hamburg.de/applets/cmos/ (9.07.2011).

30 Dr. Michio Kaku is a theoretical physicist, best-selling author, and popularizer of science. He is the co-founder of string field theory (a branch of string theory), and continues Einstein's search to unite the four fundamental forces of nature into one unified theory. See: http://mkaku.org/ (8.07.2011).

31 M. Kaku, Wizje. Czyli..., op. cit., s. 9. See also: A. Sepkowski, Człowiek a przyszłość, Toruń 2005; K. J. Stryjski, Prognozowanie i symulacje międzynarodowe, Łódź 2004; B. Guzik, D. Appenzeller, W. Jurek, Prognozowanie i symulacje. Wybrane zagadnienia, Poznań 2004; C. Rutkowski, Przeglad strategiczny jako narzędzie polityki, Warszawa 2003; M. Sułek, Metody i techniki badań stosunków międzynarodowych, Warszawa 2004; Modelowanie matematyczne i symulacje komputerowe w naukach społecznych, (eds.) K. Winkowska-Nowak, A. Nowak, A. Rychwalska, Warszawa 2007; A. Toffler, H. Toffler, Rewolucyjne bogactwo, Przeźmierowo 2007, Przyszłość i polityka. Nadzieje i strachy zbiorowe przełomu tysiacleci, (eds.) E. Ponczek, A. Sepkowski, Toruń 2008; Д. Г. Кунстлер, Что нас ждет, когда закончится нефть, изменится климат и разразятся другие катастрофы ХХІ века, "Питер" 2011. 
to the discoveries and ideas of both individuals and research teams, the world will be able to overcome the energy problems. It is worth remembering that, as Stanisław Ossowski (a Polish sociologist, methodologist of the social sciences, and cultural theorist) once said, "A researcher is a man whose professional responsibilities include lack of obedience in thought. This is his social service, performing his professional duties, not to obey in thought... the synod, committee, minister, emperor, or Lord. If he is obedient, if his views change at somebody's order, he betrays his obligations". ${ }^{32}$ May this scientific waywardness produce effects.

\begin{abstract}
Energy security is one of the targets of the energy policies adopted by modern states and more and more by supranational structures. At the same time, it is a precondition for a country's economic growth and the society's well-being. In the 21 century, we depend on both primary (like electricity) and secondary energy carriers. Among the latter, oil and natural gas played and play an important role in the foreign policies of a number of states. But for resistance from political elites and business a substantial part of energy sources, whose depletion and disastrous effects on climate are touched upon by the same people, could already be successfully replaced. The article represents a contribution to the discussion on the future of world energy production. The concepts referred to might seem pointless, unreal, or trivial, but let us hope that thanks to the discoveries and ideas of both individuals and research teams, the energy problems of the world will be overcome.
\end{abstract}

\title{
BEZPIECZEŃSTWO ENERGETYCZNE - W KLINCZU POLITYKI I BIZNESU. WYBRANE ALTERNATYWNE ROZWIĄZANIA ENERGETYCZNE
}

\section{STRESZCZENIE}

Bezpieczeństwo energetyczne jest jednym z celów polityki energetycznej prowadzonej przez współczesne państwa, a także coraz częściej przez struktury ponadnarodowe. Jest jednocześnie warunkiem rozwoju gospodarczego kraju i dobrobytu społeczeństwa. W XXI wieku jesteśmy uzależnieni zarówno od wtórnych nośników energii (jak chociażby prąd), czy pierwotnych. Wśród tych drugich - ze względu na swoje strategiczne znaczenie - ropa naftowa oraz gaz ziemny odgrywały i odgrywają istotną rolę w polityce zagranicznej wielu państw świata. Tylko, że gdyby nie opór elit politycznych i biznesu, już teraz część źródeł energii - o których wyczerpywaniu się czy zgubnym wpływie na klimat słyszymy od tych samych osób, można by z powodzeniem zastapić innymi. Artykuł jest przyczynkiem do dyskusji nt. przyszłości światowej energetyki: przywoływane w nim koncepcje wydawać się mogą chybione, nierealne czy trywialne, ale trzeba mieć nadzieję, że dzięki odkryciom oraz pomysłom zarówno pojedynczych osób, jak i zespołów badawczych świat zdoła przezwyciężyć problemy energetyczne.

32 J. Jeszke, Nauka $w$ dziejach kultury europejskiej, http://www.amu.edu.pl/ jeszke/uploads/File/Nauka\%20w\%20dziejach\%20kultury\%20europejskiej.ppt. (8.07.2011). 